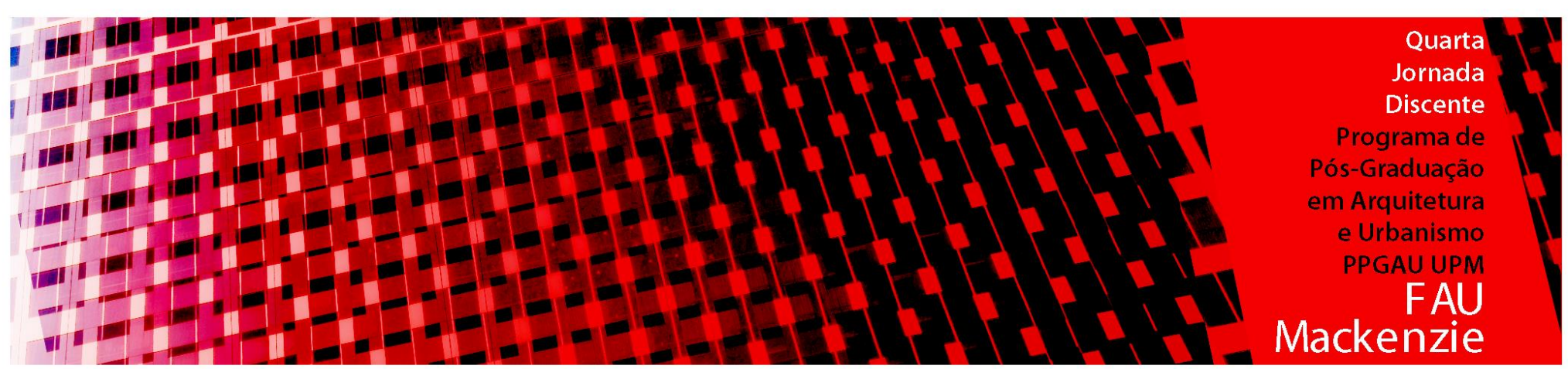

\title{
INTERVENÇÕES EM EDIFÍCIO TOMBADO NA CIDADE DE SÃO LUÍS DO PARAITINGA - ESTADO DE SÃO PAULO
}

\section{INTERVENTIONS IN BUILDING TAKEN IN THE CITY OF SÃO LUÍS DO PARAITINGA - STATE OF SÃO PAULO}

\author{
Eduardo Adalberto Jaccoud Jr¹, Dra Maria Augusta Justi Pisani²
}

\footnotetext{
${ }^{1}$ Mestrando na Faculdade de Arquitetura e Urbanismo da Universidade Presbiteriana Mackenzie, São Paulo, SP - Brasil. Alameda Casa Branca, 615, apartamento 51, São Paulo, SP, Brasil; arquiteturajaccoud@live.com

${ }^{2}$ Professora Doutora, Universidade Presbiteriana Mackenzie. Rua Itambé 45, Higienópolis - São Paulo, SP

- Brasil; augusta@mackenzie.br
} 


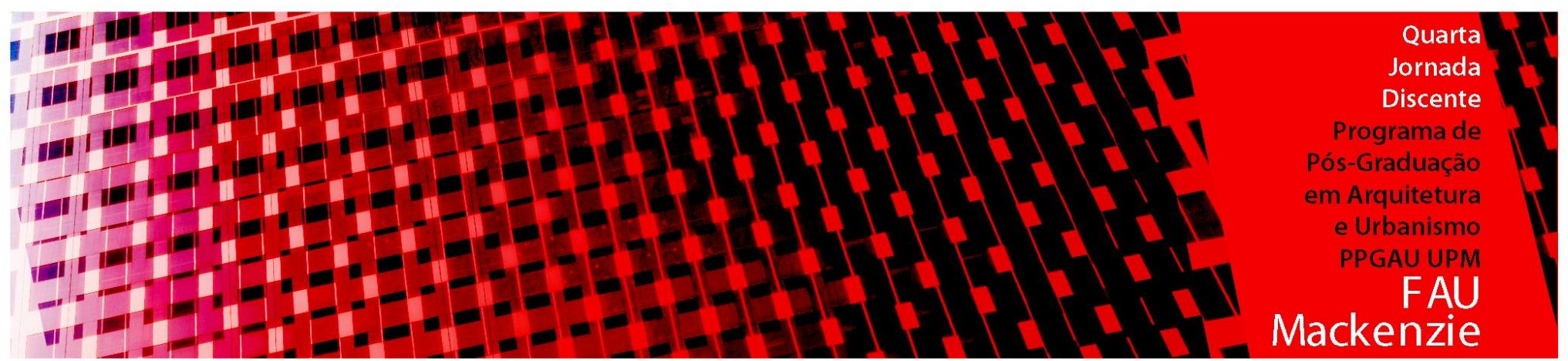

\title{
RESUMO
}

O objetivo deste artigo é descrever as intervenções realizadas em um edifício tombado, na cidade de São Luís do Paraitinga - Estado de São Paulo, em 1956 pelo seu proprietário o Sr. João Guimarães. Este edifício está localizado na Praça Dr. Oswaldo Cruz, centro e faz parte do patrimônio arquitetônico, tombado pelo Conselho de Defesa do Patrimônio Histórico, Arqueológico, Artístico e Turístico do Estado de São Paulo em 1982 e pelo Instituto do Patrimônio Histórico e Artístico Nacional em 2012 após a grande enchente do Rio Paraitinga em janeiro de 2010.

A sua importância histórica vai além da sua técnica construtiva, como suas vedações em pau-a-pique, ou taipa de mão, estrutura em pilares de pedra e piso em assoalho de madeira, características presentes em alguns imóveis da arquitetura colonial paulista de São Luís do Paraitinga. Neste edifício, ocorreu a celebração de um dos marcos progressistas significativos da cidade com a chegada da luz elétrica. Este edifício demonstra o marco da passagem do café na região do Vale do Paraíba e a influência em sua arquitetura preservada até os dias atuais. Os resultados desta pesquisa serão de grande valia quando outros restauros e/ou obras de manutenção forem necessários.

Palavra chave: Patrimônio arquitetônico, intervenção em edifício tombado, arquitetura de São Luís do Paraitinga.

\begin{abstract}
The objective of this article is to describe the interventions carried out in a listed building, in the city of. In 1956 by its owner Mr. João Guimarães. This building is located in Dr. Oswaldo Cruz Square, downtown and is part of the architectural patrimony, registered by the Council of Defense of the Historical, Archaeological, Artistic and Tourist Patrimony of the State of São Paulo in 1982 and by the Institute of National Historical and Artistic Patrimony in 2012 after the great flood of the Paraitinga River in January 2010.

Its historical importance goes beyond its constructive technique, such as its fence in stick-a-piique, or handtaipa, structure in stone pillars and floor in wood floor, characteristics present in some properties of the colonial architecture of São Luís of Paraitinga. In this building, there was the celebration of one of the city's significant progressive landmarks with the arrival of electric light. This building demonstrates the landmark of the passage of coffee in the region of the Paraíba Valley and the influence in its architecture preserved to the present day. The results of this research will be of great value when other restorations and / or maintenance works are necessary.
\end{abstract}

Key words: Architectural heritage, intervention in a listed building, architecture of São Luís do Paraitinga. 


\section{INTRODUÇÃO}

A finalidade deste artigo é analisar as intervenções realizadas em 1956 em um edifício construído no final do século XIX, localizado na cidade de São Luís do Paraitinga - Estado de São Paulo.

A análise será realizada a partir do levantamento arquitetônico do final da década de 1970 elaborada pelo Condephaat - Conselho de Defesa do Patrimônio Histórico, Arqueológico, Artístico e Turístico, que teve como objetivo inventariar esse bem cultural e posteriormente realizar o seu tombamento. $\mathrm{O}$ método empregado para esta pesquisa se fundamentou em dados secundários e primários, principalmente com levantamentos de campo e entrevistas com a Sra. Maria Silvia Guimarães, filha do Sr. João Guimarães, proprietário do imóvel e realizador da intervenção.

A obra realizada em 1956 ocorreu antes do tombamento do edifício e da Carta de Veneza, de 1964, que definia as diretrizes de conservação e restauração em edifícios históricos, com a finalidade de salvaguardar tanto a obra de arte quanto o seu testemunho histórico:

[...]Art. $4^{\circ} \mathrm{A}$ conservação de monumentos exige antes de tudo, manutenção permanente. [...]Art. $10^{\circ}$ Quando as técnicas tradicionais se revelarem inadequadas a consolidação do monumento pode ser assegurada com o emprego de todas as técnicas modernas de conservação e construção cuja eficácia tenha sido demonstrada por dados científicos e comprovada pela eficiência[...] (CURY, 2004, p. 92-93)

Este trabalho registra a intervenção que contribuiu para a preservação e manutenção desta edificação até os dias atuais, pois vale lembrar que em no dia 01 de janeiro de 2010, a cidade de São Luís do Paraitinga teve uma de suas maiores enchentes do Rio Paraitinga e grande parte do seu conjunto arquitetônico como: sobrados, casas térreas, igreja matriz de São Luís de Tolosa, Capela de Nossa Senhora das Mercês, entre outras foram totalmente destruídos (VERDE; SCHICHI, 2013). O sobrado estudado resistiu á catástrofe e não ruiu como muitos da cidade e, provavelmente ele sobreviveu às inundações devido aos reforços executados na reforma ora registrada.

Com este documento ficará registrado a descrição das intervenções realizadas neste edifício histórico, para que este possa servir como apoio para as futuras intervenções, restauros e manutenções.

\section{O SOBRADO}

O sobrado do final do século XIX, localizado na Praça Dr. Oswaldo Cruz, ${ }^{\circ} 04$ no centro histórico da cidade de São Luís do Paraitinga - Estado de São Paulo e é um testemunho da arquitetura urbana tradicional paulista (SAIA, 1972 e LEMOS, 1999). Apresenta a estrutura de madeira denominada de "gaiola" executada com canela preta (Ocotea catharinensis) e vedações de pau-apique elaborado com trama de bambu e preenchidas por massa de argila local, conforme descritos por Vasconcellos (1961) e Pisani (2004).

A Fig.1 apresenta as plantas originais do pavimento térreo e superior, onde a estrutura de gaiola de madeira se assenta em colunas de pedra bruta argamassada. $\mathrm{O}$ espaço interno do pavimento superior é dividido em três partes: o fronteiro nobre, como: as salas de estar e os quartos, o posterior, com sala de jantar, alcovas que se abrem para ambos e a área de serviço com a cozinha e banheiro. 

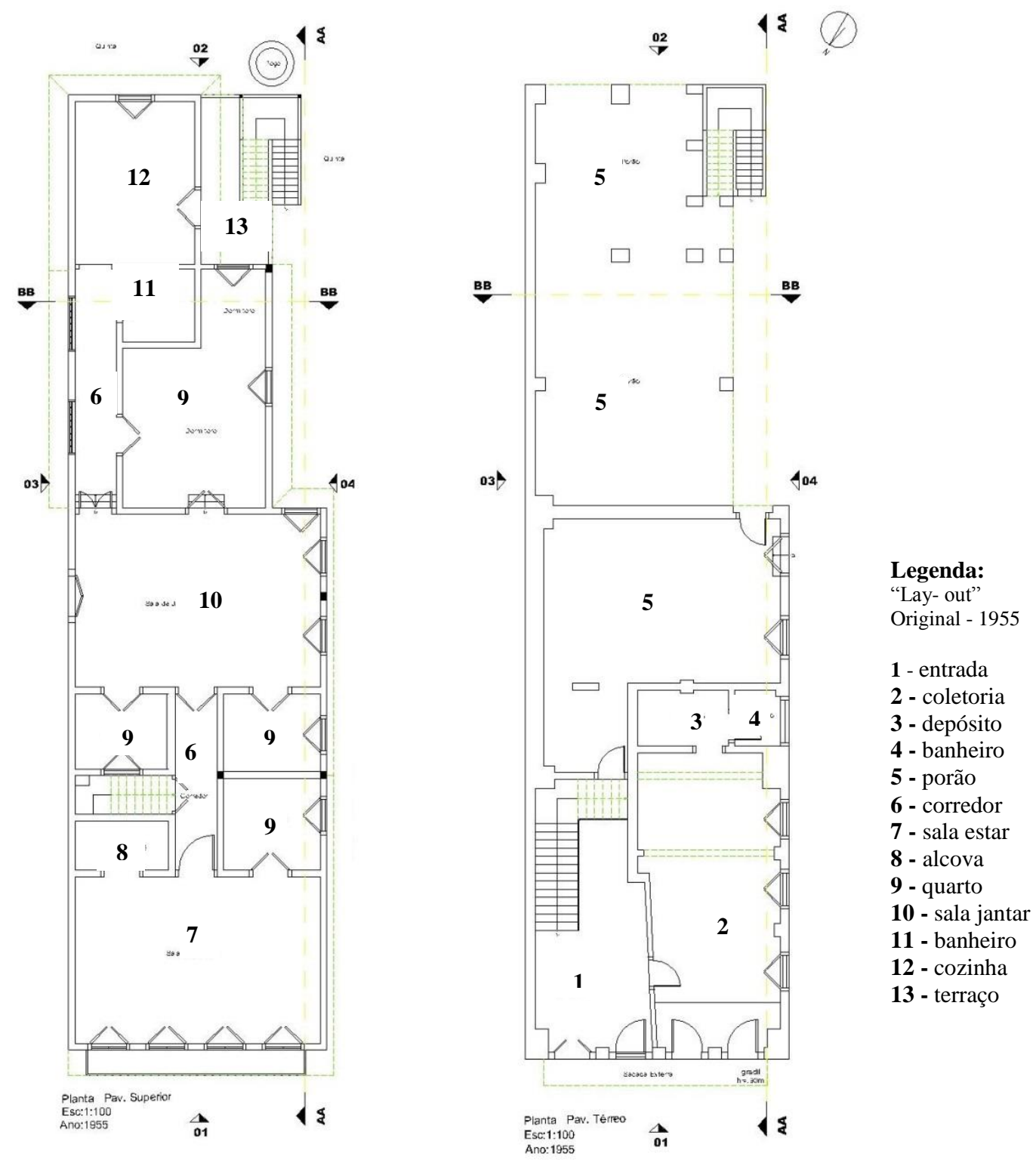

Figura 1: Plantas do pavimento térreo o superior - original - 1955

Fonte: desenhos elaborados a partir do KAMIMURA (1972) e levantamento "in loco".

No pavimento térreo a gaiola se assenta em colunas de pedra bruta argamassada. O espaço interno do pavimento superior é dividido em três partes: o fronteiro nobre, como: as salas de estar e os quartos, o posterior, com sala de jantar, alcovas que se abrem para ambos e a área de serviço com a cozinha e banheiro.

Quanto às demais técnicas construtivas, o piso superior (Figuras 2 e 4) é constituído por um tabuado - assoalho de madeira sobre "barrotes" quadrados em madeira de lei engastada nas colunas estruturais em pedra do pavimento térreo, forros em tábua na forma de "saia e camisa" nos ambientes como a sala de estar e a sala secundária, sendo que esta possui ornatos em madeira entalhados, compostos por medalhão centralizado e enquadrados por uma moldura, e outros elementos decorativos, detalhe observado na Fig. 3. 


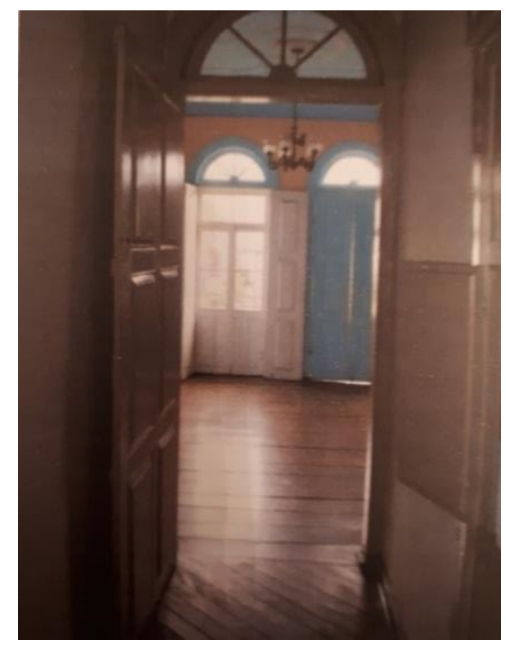

Figura 2: Vista interna: sala de estar - (ft.1) Fonte: Jaccoud (2007)

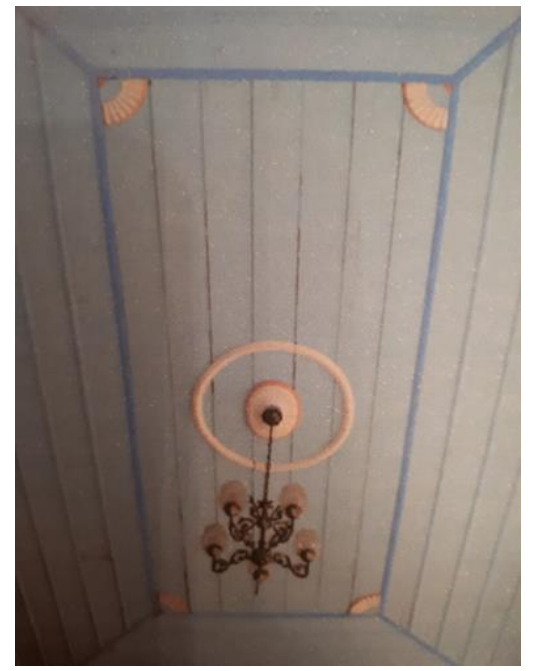

Figura 3: Vista interna: detalhe do forro - (ft.2) Fonte: Jaccoud (2007)

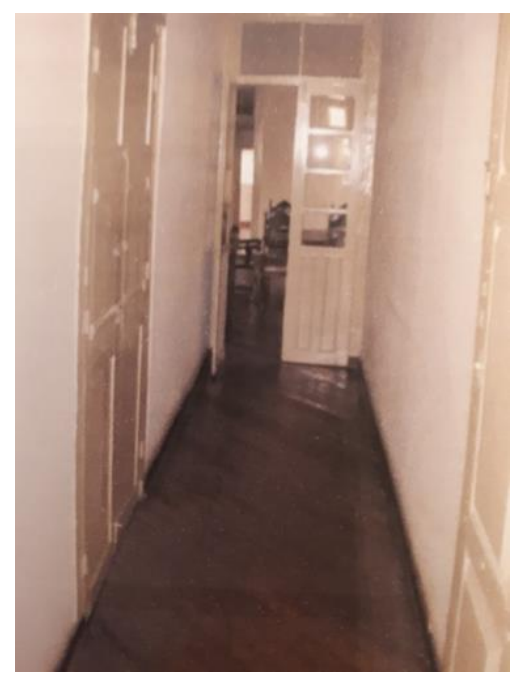

Figura 4 - Vista do corredor interno - (ft.3) Fonte: Jaccoud (2007) 
A escada é de madeira maciça e as portas e janelas da fachada apresentam-se com uma ou duas folhas almofadadas, bandeiras em arco pleno envidraçadas com abertura para a Praça Dr. Oswaldo Cruz, ficando protegidas por um balcão de ferro fundido com desenhos variados, conforme a Figura 5, que apresenta a fachada do sobrado em 1921.

O edifício que faz parte do conjunto arquitetônico histórico foi tombado pelo Condephaat em 13 de maio de 1982, cujo processo é n 22066/82, e está classificado no Grau de proteção GP 1A definida a categoria como uma edificação anterior ao século XX, que recebeu modificações mais acentuadas, em relação aos edifícios que receberam o GP1. Em razão das sucessivas adaptações, decorrentes as novas funções urbanas, onde a mesma se torna igualmente susceptível a restauração, através de métodos científicos comprovados. Sua categoria tipológica é classificada como $\mathrm{n}^{\circ} 5$, conforme a descrição:

Casa de sobrado constituído por residência no pavimento superior, pavimento térreo eram destinado ás atividades comerciais, alojamento de escravos ou depósitos, sendo que o pavimento superior era exclusivamente utilizado a moradia dos proprietários. (CONDEPHAAT,1982, p.66).

No dia 05 de dezembro de 2012 este imóvel e a cidade de São Luís do Paraitinga, foram tombados pelo IPHAN - Instituto do Patrimônio Histórico e Artístico Nacional, cujo o processo é de $\mathrm{n}^{\circ} 1590$ T-10. Conforme tombamento do centro histórico e paisagístico de São Luís do Paraitinga ficou determinado que os casarões, as capelas, as praças, os coretos e fontes, as ladeiras, as ruas e os largos são: marcos de preservação urbana; acentuadas referências espaciais da cidade e testemunhos das fases de sua expansão urbana (IPHAN, 2012).

Na Figura 5 podemos observar a fachada do edifício em 1921, onde se encontra o balcão externo inteiriço e a as folhas de guilhotina envidraçadas presentes ao lado direito da porta principal de acesso ao pavimento superior.

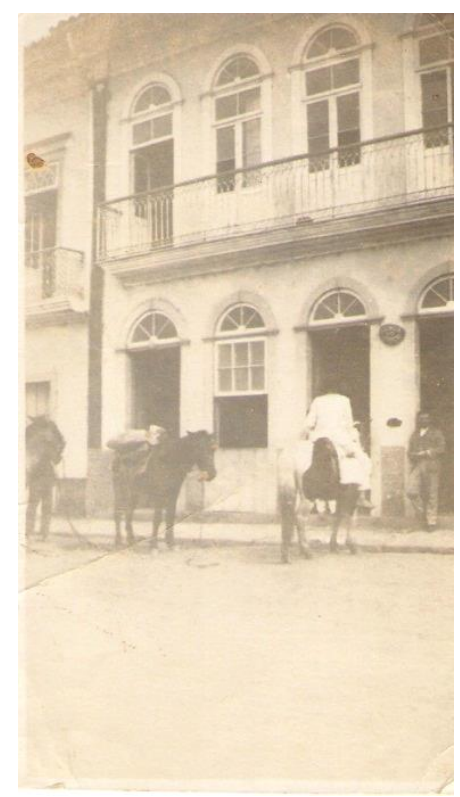

Figura 5: Fachada em 1921

Fonte: Guimarães (1921)

A Fig. 6 ilustra a fachada de 2018, sem o antigo balcão contínuo e passa ter gradis em cada porta e a janela de guilhotina existente na (Fig. 5) foi retirada. 


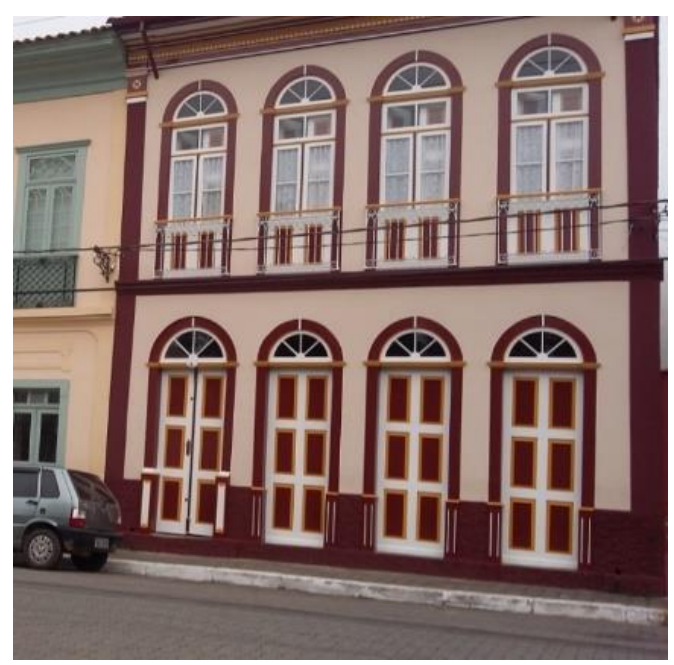

Figura 6: Fachada em 2018

Fonte: Jaccoud (2018)

Durante os levantamentos de campo realizados na cidade, um fato interessante sobre este sobrado em estudo foi encontrado na Capsula do Tempo (1927), um manuscrito relevante para a história da cidade e deste sobrado, apresentado nas (Fig. 7 e 8), que descreve:

A luz electrica desta esteve em projeto durante trêz annos. Em 1923 fizeram uma sociedade os homens de dinheiro desta e combinaram de fazer a luz por conta deles: que durou um ano o serviço. O dínamo o volante essas peças grandes e pesadas vieram de tractor por serem grandes e pesadas não puderam vir em carro de boi. Em 1924 quando fizeram a esperiencia foi um sucesso ficou linda a cidade. Então no dia de Reis dia 6 de janeiro de 1924 ficou a luz desta cidade inaugurada. No dia 6 pelas 2 horas choveu até as 3.O pessoal ficaram sem esperança em ver sua inauguração. Mas as 6 horas de corporação musical Sta. Cecilia o pessoal do Directorio Politico, moças, crianças e etc vieram ao coreto. Assim que chegaram a luz deu a sua segunda luz em nossa terra. No coreto municipal teve muitos discursos etc. As 7 horas da noite teve um grande baile que foi até as 2 e meia da manhã na casa do Sr. Romillo Guimarães. (CAPSULA DO TEMPO, 1927, p. 15).

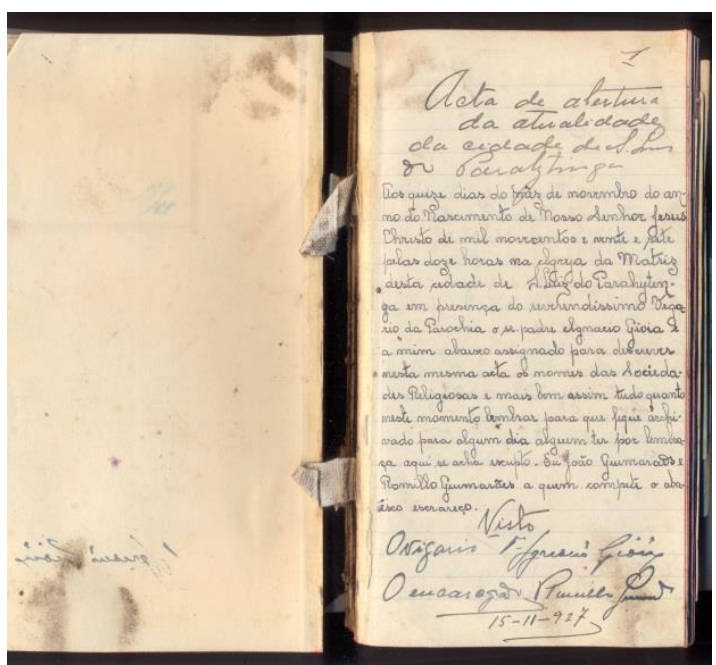

Figura 7: Página 1 do caderno de anotações Fonte: Capsula do Tempo (1927) 


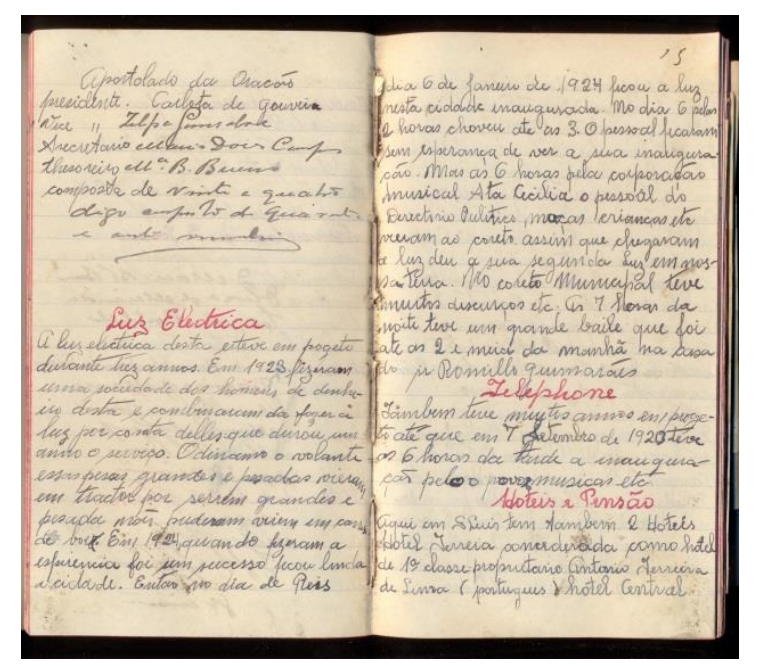

Figura 8: Página 15 do caderno de anotações Fonte: Capsula do Tempo (1927)

A primeira página da "Acta de abertura das atualidades da Cidade de São Luís do Parahytinga" (Fig. 7), foi escrita pelo Sr. João Guimarães aos seus 14 anos de idade na presença de seu pai o Sr. Romillo Guimarães, proprietário do sobrado na época, no dia 15 de novembro de 1927. Esta ata de atualidades foi escrita também sobre a anuência e na presença do Vigário Ignácio Gióia, na cidade de São Luís do Paraitinga, com o intuito de registrar o nome das sociedades religiosas e todos os fatos importantes da sociedade ocorridos na cidade até aquele momento. Este documento encontrado lacrado na Igreja Matriz se tornou precioso para o resgate da história de São Luís do Paraitinga.

Na página 15 do mesmo caderno (Fig. 8) está registrada a inauguração da rede de energia elétrica na cidade de São Luís do Paraitinga, que ocorreu no dia 06 de janeiro de 1924, sobre a presença de autoridades da cidade, mulheres e crianças a luz elétrica foi ligada na cidade, com muitos discursos no coreto da praça e, posteriormente, houve um grande baile de comemoração a este fato na residência do Sr. Romillo Guimarães, residência esta que é o objeto de estudo deste artigo.

O Sr. Romillo Guimarães era Coletor do Estado (responsável pela arrecadação de impostos, que funcionava no pavimento térreo desta edificação), foi um dos financiadores da eletrificação da cidade, residia neste edifício e era o pai do Sr. João Guimarães que realizou esta intervenção em 1956, sendo que esta edificação se mantém preservada sobre a posse de seus descendentes.

\section{A INTERVENÇÃO}

No ano de 1956, o edifício passou por uma intervenção realizada pelo seu proprietário o Sr. João Guimarães, onde ocorreram algumas alterações com as técnicas construtivas díspares das originais, no seu programa de necessidades e nas subdivisões dos espaços internos. Inicialmente esse processo foi realizado em apenas uma parte do imóvel, no pavimento superior no segundo corpo do edifício onde estava localizado o corredor lateral que ligava a sala de jantar e a cozinha. Esta área foi o setor mais significativo desta intervenção. Já no pavimento térreo pouco se alterou: houve a substituição das janelas de madeira com vidraçaria de guilhotina; a retirada de uma vidraçaria que não era original e foi inserida sobre um balcão móvel localizado na segunda porta do lado direito de quem olha para a fachada principal (Fig. 5) e o fechamento de uma porta de acesso à entrada principal no espaço lateral antes utilizado como repartição pública - Caixa 
Econômica Estadual - Coletoria que ali funcionou por muitos anos, conforme pode ser observado na (Fig. 1 e 10) nas plantas do pavimento térreo.

A intervenção ocorreu pelo motivo do edifício apresentar degradações em suas vedações internas e externas de pau-a-pique; perda da massa de barro que compunha o tramado de bambu; apodrecimento no piso de assoalho do banheiro e cozinha, bem como patologias pelo ataque dos insetos xilófagos nos batentes das janelas e nos pisos. Diante desta situação houve a decisão de intervir para que a edificação não entrasse em ruína, como ocorria na cidade com outras construções similares.

Na intervenção de 1956, de responsabilidade do proprietário, ocorreram as seguintes alterações: a) O corredor: no pavimento superior (Fig. 11) a intervenção realizada em 1956, ocorreu no eixo do corredor de ligação entre a sala de jantar e a cozinha, onde o mesmo, que era lateral, foi centralizado (Fig. 9), permitindo a distribuição de 3 dormitórios à direita e à esquerda 1 dormitório e 1 banheiro com janelas, pois o primitivo não possuía iluminação e ventilação natural. Nesta área os pisos anteriormente de madeira passaram a serem substituídos por um ripamento de palmeira de Jussara, Juçara e/ou Içara", ${ }^{1}$ composta por uma estrutura de ripamento, enfileirados fixados por pregos diretamente no barrote estrutural de madeira com secção quadrada de 15 x $15 \mathrm{~cm}$ e recoberto por uma camada maciça de uma argamassa mista de cimento, cal, areia e seixo de rio, detalhe observado na Figura 19;

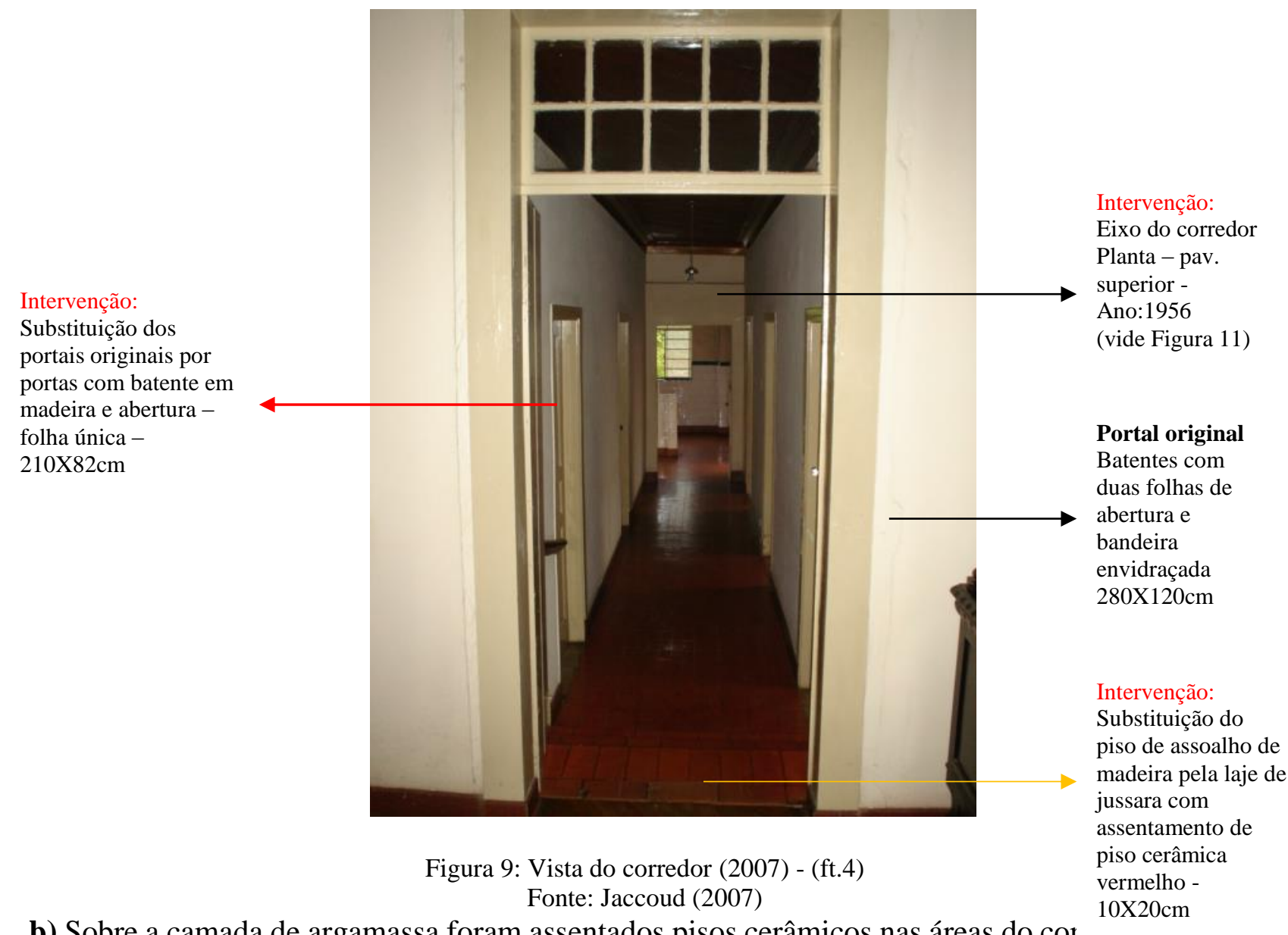

b) Sobre a camada de argamassa foram assentados pisos cerâmicos nas áreas do cor e banheiro, enquanto nos quartos foram aplicados taco de madeira de peroba rosa;

${ }^{1}$ Palmeira de Jussara, Juçara e/ou Içara - (Euterpe edulis) Palmeira nativa da Mata Atlântica, que dá o palmito tipo Juçara em extinção e sua madeira era utilizada na confecção de ripas. 
c) No terraço antes constituído por piso de madeira juntamente com a escada que acessa o quintal também foram executados o lastro de argamassa e sobre este foram assentados pisos de ladrilho hidráulico;

d) A escada, originalmente em madeira, foi substituída por uma executada com alvenaria de tijolos maciços comuns, mantendo o desenho original dos degraus;

e) As caixilharias anteriormente em madeira com folhas de guilhotina envidraçadas foram substituídas por basculantes de ferro e as demais com esquadria de folhas de correr, conforme pode ser observada nas Fig. 12, 13 e 14;

f) Substituição das vedações internas e externas de pau-a-pique para alvenaria de tijolos maciços comuns, assentados com solo cimento, mistura feita de argila, cimento e água, conforme pode ser observada na Fig. 16;

g) Substituição nas telhas coloniais de barro - águas dos fundos pelas telhas francesas, mantendo apenas o telhamento original a água frontal voltada para a Praça Dr. Oswaldo Cruz;

h) Retirada do balcão contínuo e a inserção dos gradis isolados nas janelas.

Nas Fig. 10 e 11 a seguir, observamos as alterações em planta com as devidas legendas.

\subsection{Plantas}



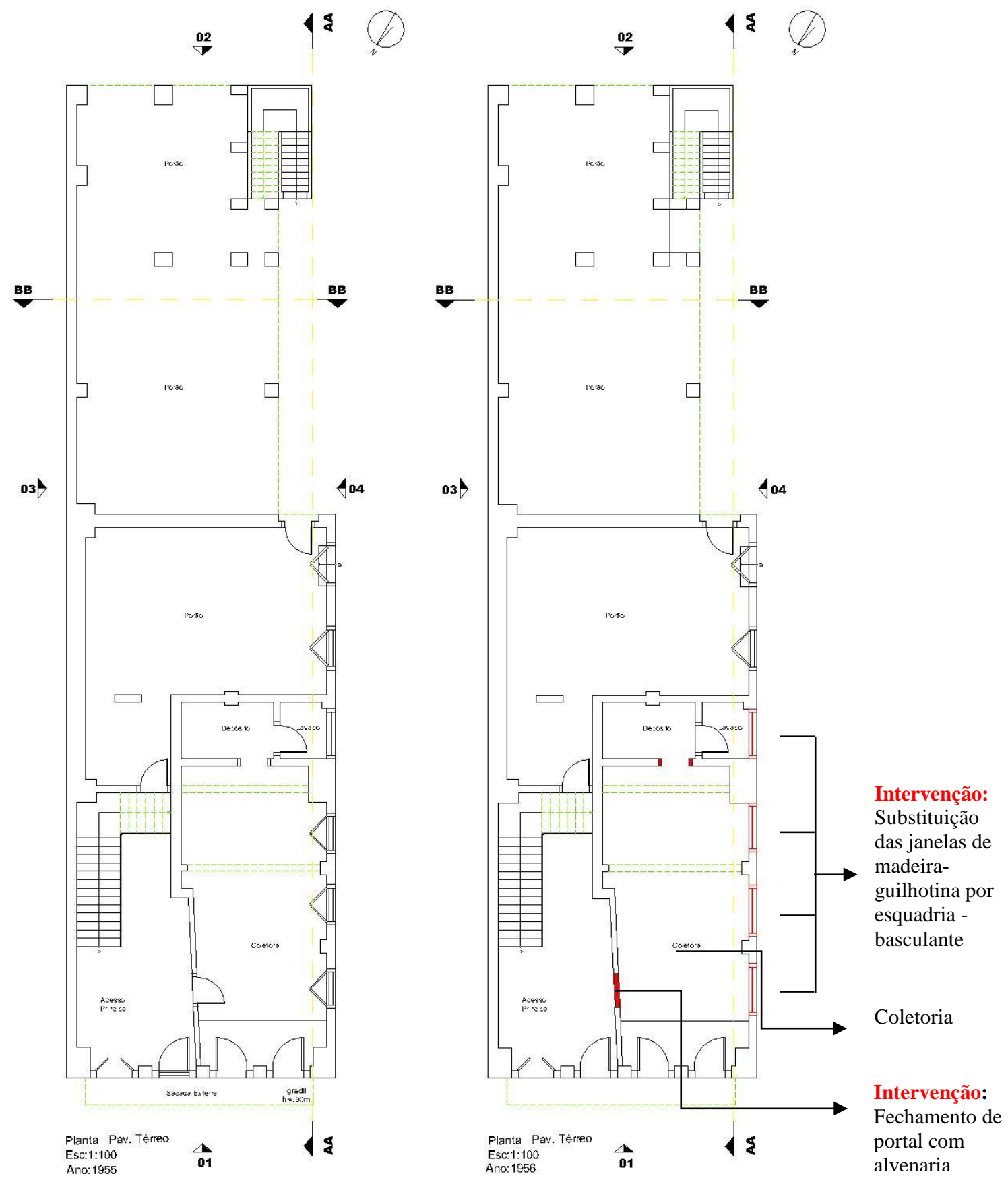

Figura 10: Plantas do pavimento térreo, original de 1955 (à esquerda) e com as intervenções de 1956 (à direita). Fonte: desenhos elaborados a partir do KAMIMURA (1972) e levantamento "in loco".

Na Fig. 10, podemos observar as plantas do pavimento térreo, original de 1955

(esquerda) e a planta de 1956 com as intervenções em 1956 (direita). As intervenções realizadas foram: a substituição das janelas de madeira - guilhotina por esquadria de aço - basculante e o fechamento do portal de acesso da entrada interna da residência (as duas portas a esquerda) com a área utilizada para comércio (as duas portas a direita), onde era a Coletoria Estadual, posteriormente a Caixa Econômica Estadual.

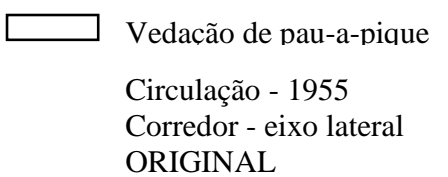
ORIGINAL
Vedação de tijolo de barro - intervenção

Circulação - 1956

Corredor - eixo centralizado INTERVENÇÃO 

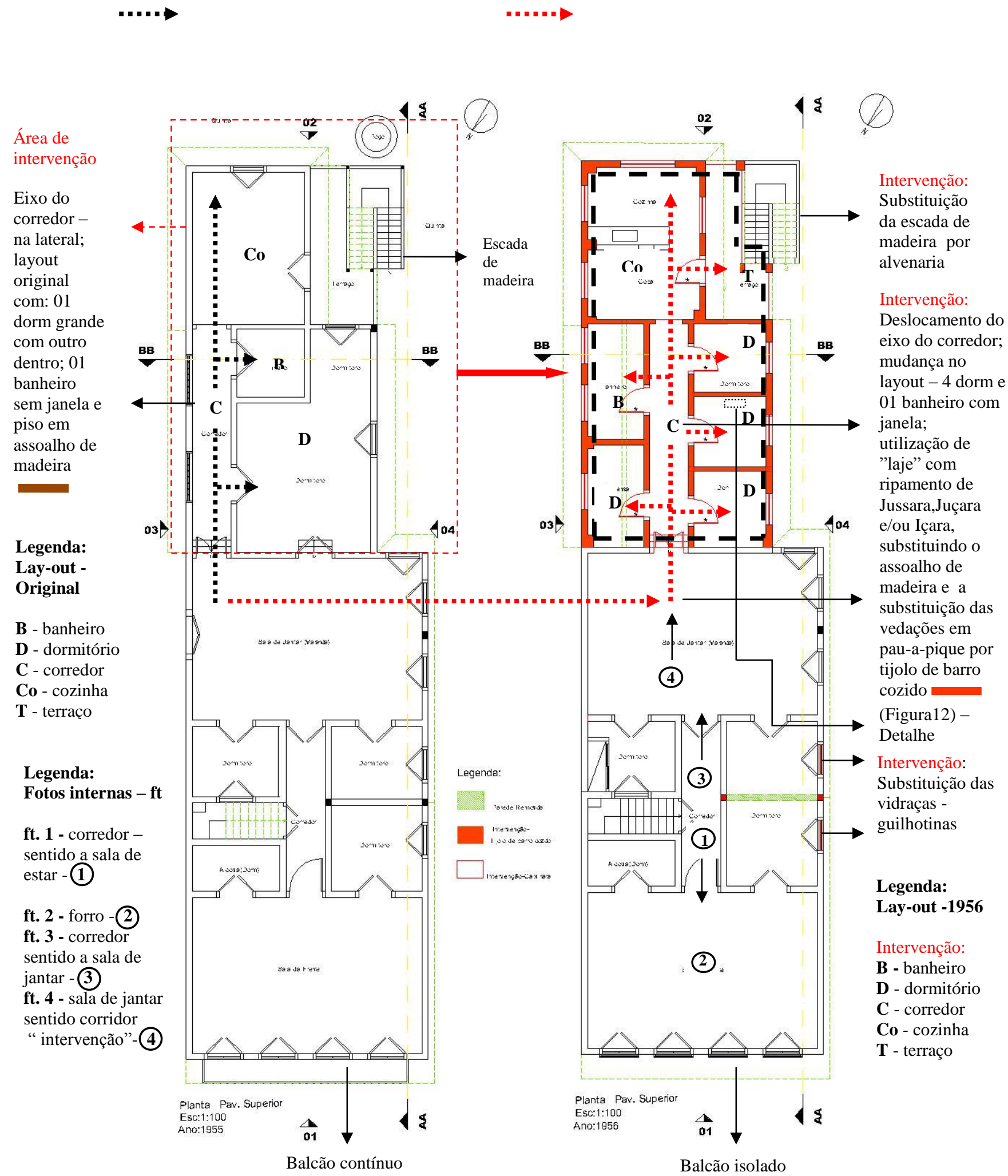

Figura 11: Plantas do pavimento superior, original de 1955 (à esquerda) e com as intervenções de 1956 (à direita). Fonte: desenhos elaborados a partir do KAMIMURA (1972) e levantamentos "in loco".

\subsection{Fachadas}


$\mathrm{Na}$ fachada original Fig. 5 permaneceu até o ano de 1955, onde podemos observar a presença do balcão externo contínuo unindo as quatro janelas envidraçadas do pavimento superior. No pavimento térreo notamos a presença da vidraça guilhotina na segunda porta direita. Após a sua intervenção em 1956 o balcão foi recuado e fixado de forma isolada a cada janela e foi retirada a vidraça de guilhotina da porta no pavimento térreo Fig. 6.

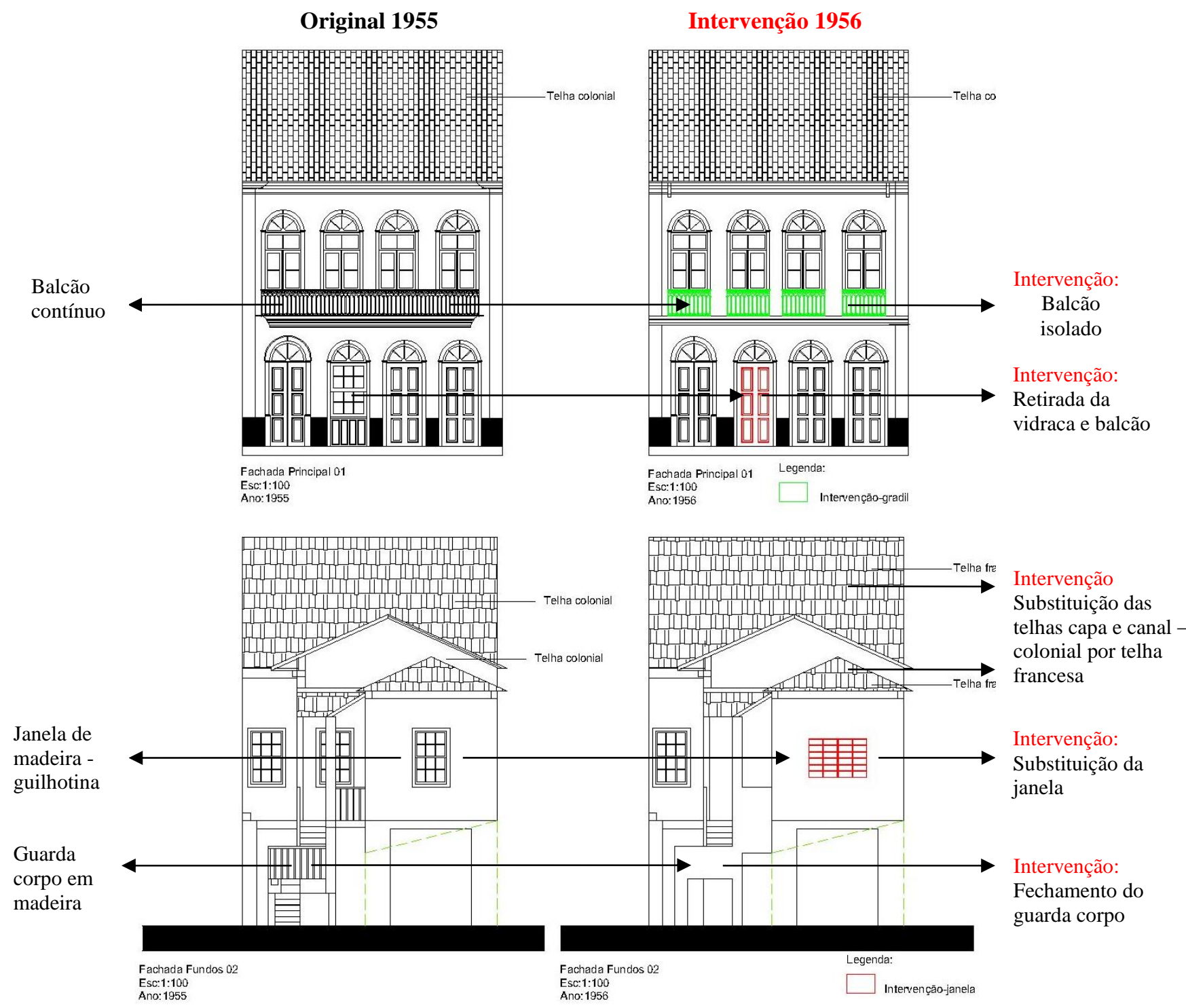

Figura 12: Fachada principal - 01 e Fachada fundos - 02, original de 1955 (a direita) e com as intervenções de 1956. Fonte: desenhos elaborados a partir do KAMIMURA (1972) e levantamento "in loco".

Na Fig. 12, fachada - fundos - 02, no primeiro momento apresenta a janela da cozinha e a escada de acesso ao quintal em madeira e após a intervenção de 1956 notamos a substituição da janela e da escada.

Na Fig. 13, demonstramos as diversas alterações feitas nas aberturas em 1955 e 1956, tais como: a) Janelas em madeira originais substituídas pelas esquadrias de aço; 
b) Porta original de madeira em duas folhas substituída por outra de única folha;

c) Janela acrescentada na área da cozinha e

d) Guarda corpo original feito em madeira maciça foi substituído por alvenaria de tijolo maciço comum revestido com argamassa;

e) Retirada do balcão contínuo e inserção dos gradis isolados nas janelas.

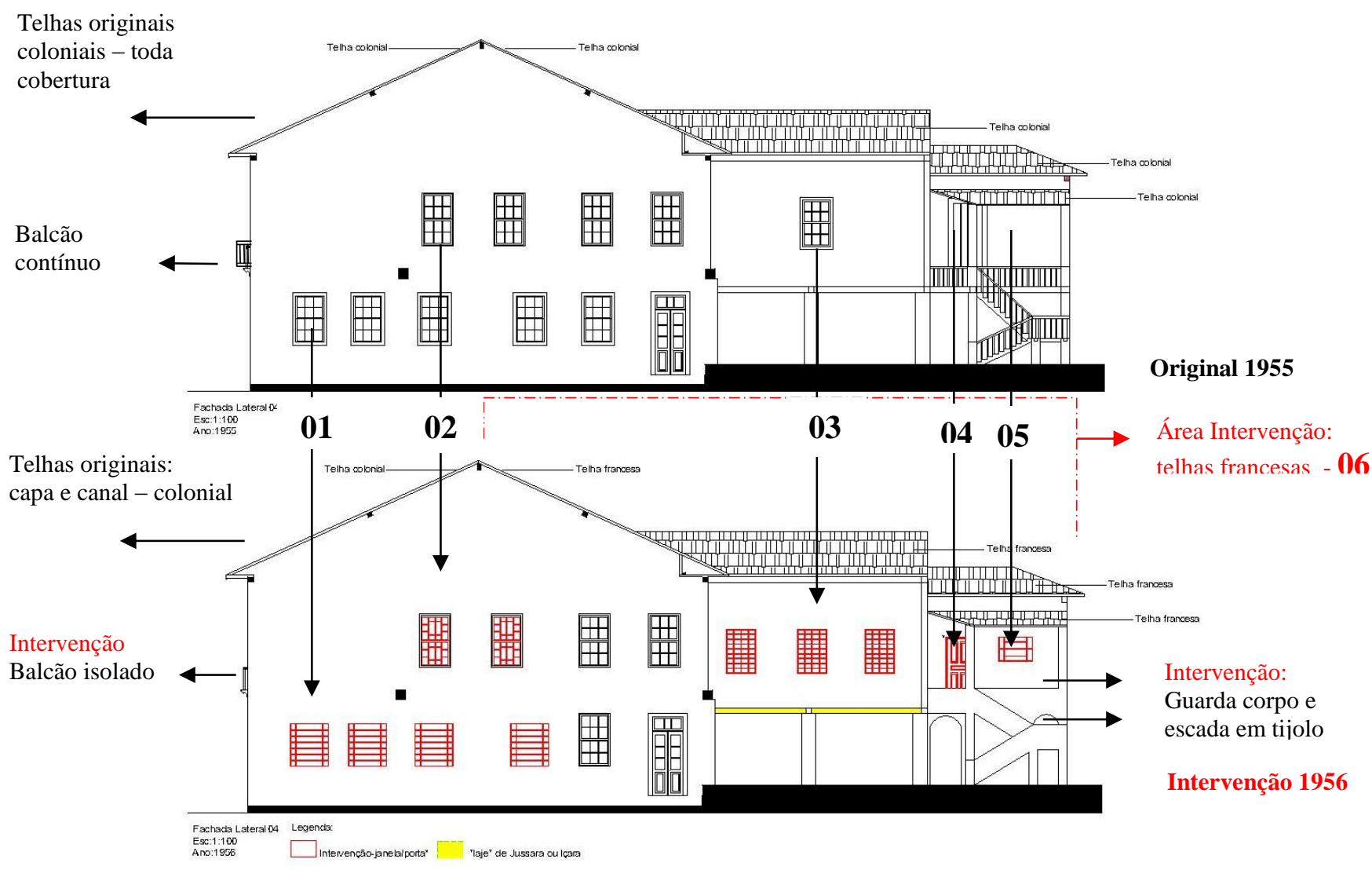

Figura 13: Fachada lateral - 04, original de 1955 e com as intervenções de 1956.

Fonte: desenhos elaborados a partir do KAMIMURA (1972) e levantamento "in loco".

\section{Intervenção:}

01 - Substituição da Vidraçaria - guilhotina

02 - Substituição de janela de madeira - tipo: guilhotina por vitrô - "basculante"

$\mathbf{0 3}$ - Substituição e adição de vitrô - abertura de correr

04 - Substituição da porta da cozinha - acesso terraço

05 - Instalação de janela

06 - Substituição das telhas capa e canal - colonial por telhas francesas - parte dos fundos 
Na fachada lateral 03, (Fig. 14), original até 1955 e posterior ás intervenções de 1956, podemos observar que após a mudança do eixo do corredor e do layout deste espaço interno no pavimento superior, conforme pode ser observada na (Fig. 11) planta do pavimento superior - intervenção 1956, na cozinha antes inexistente a abertura de janelas nesta empena, na intervenção foram feitas duas aberturas para a instalação de duas esquadrias basculantes - 01, oferecendo melhorias de ventilação e iluminação interna neste espaço. No banheiro instalação de esquadrias de aço "basculante" - 02, vieram substituir as duas janelas em meio arco de madeira com vidro presentes no corredor original.

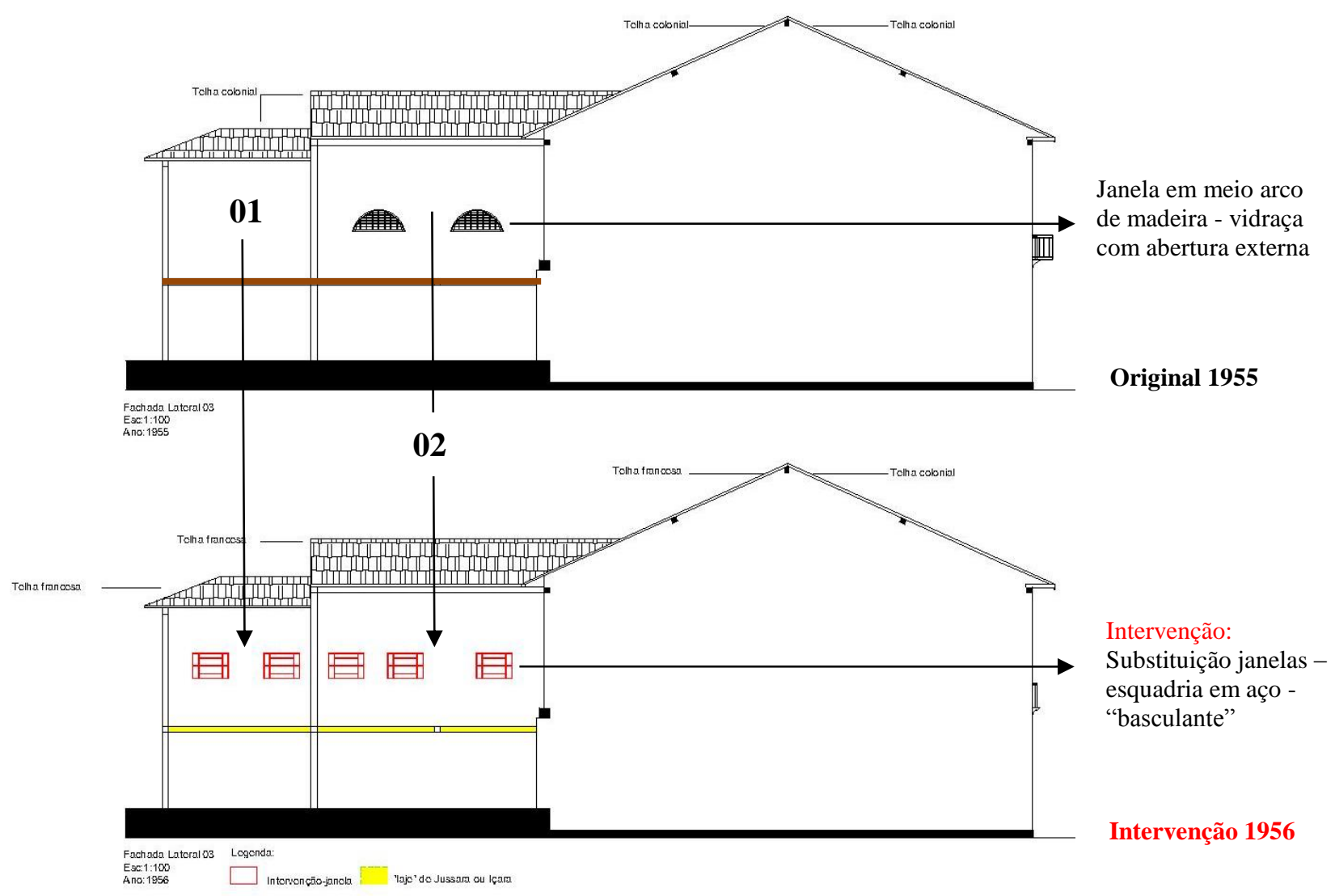

Figura 14: Fachada lateral - 03, original de 1955 e com as intervenções de 1956.

Fonte: desenhos elaborados a partir do KAMIMURA (1972) e levantamento "in loco".

\section{Intervenção:}

01- Abertura de janelas

02- Instalação de janelas - esquadria em aço -"basculante" 


\subsection{Cortes}

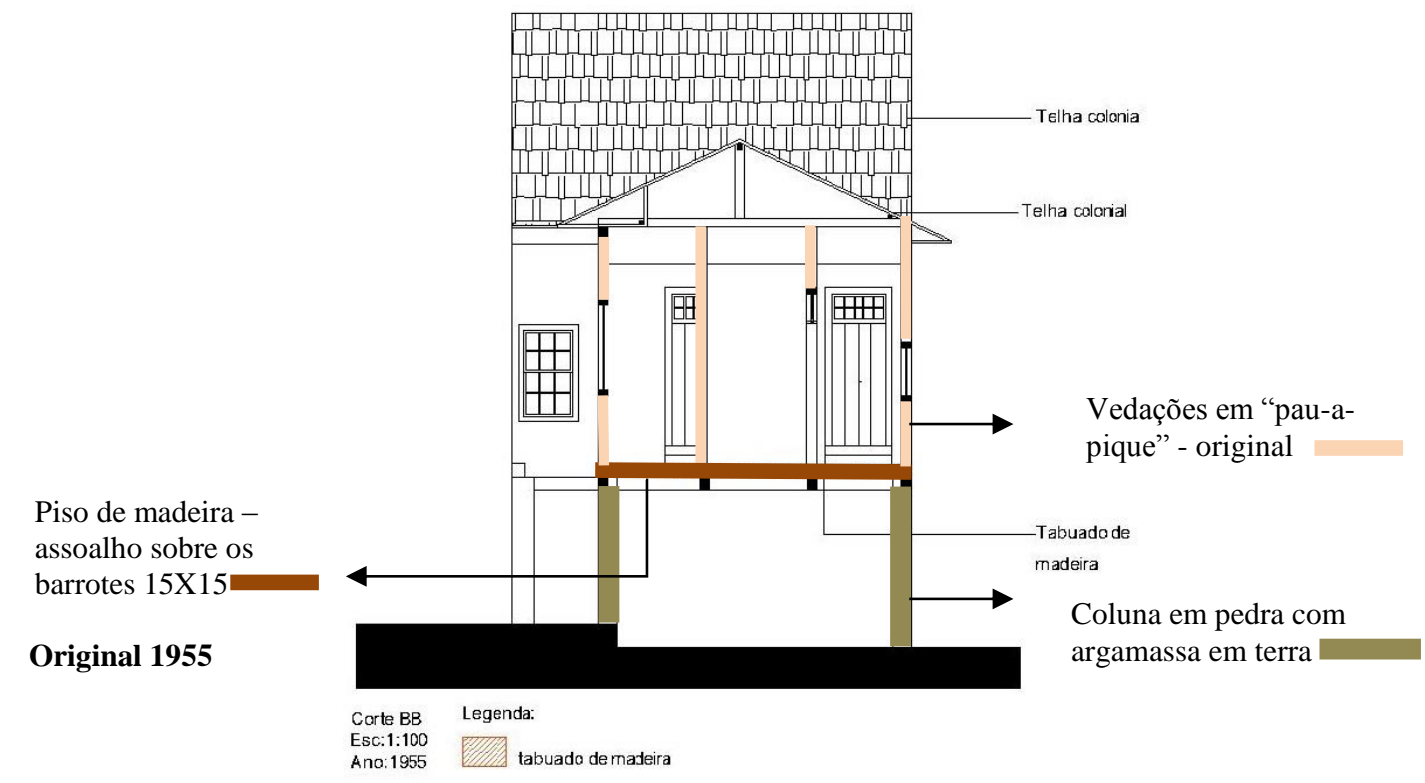

Intervenção:

Substituição do assoalho de madeira por uma "laje" com ripamento de "Jussara, Juçara e/ou Içara

Intervenção 1956

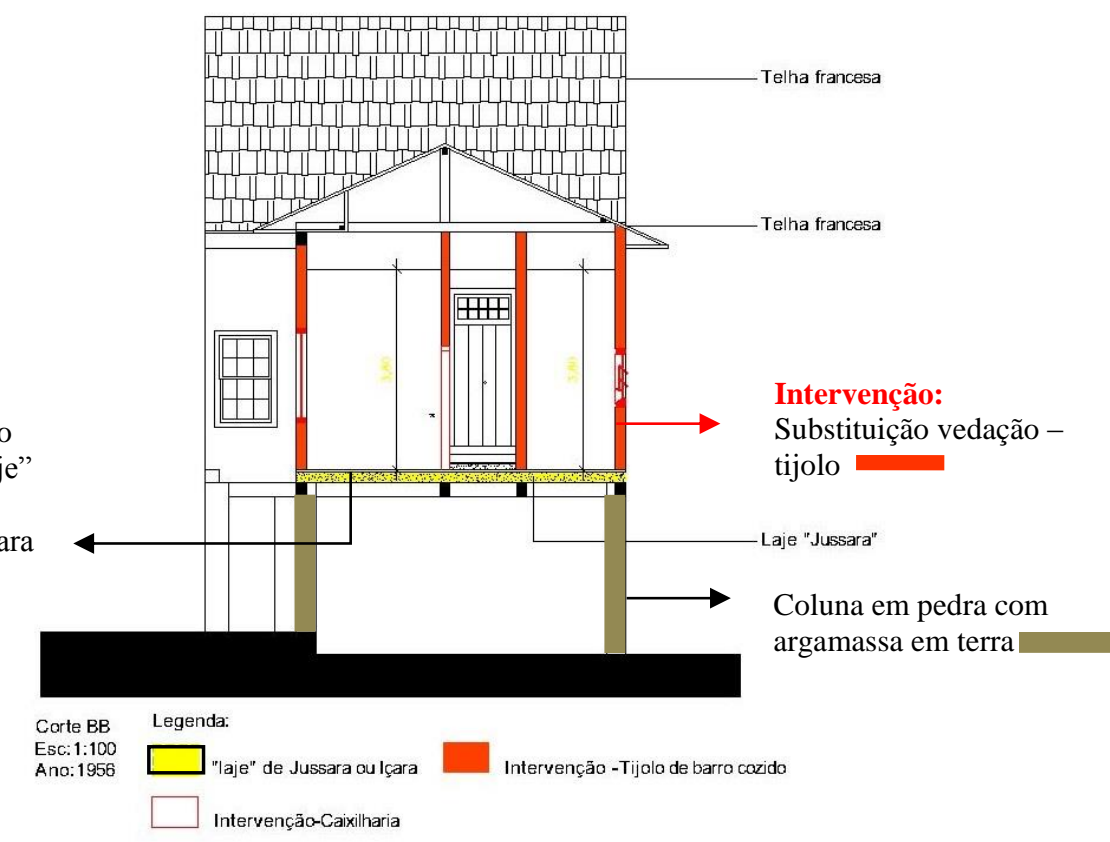

Figura15: Corte BB, original de 1955 e com as intervenções de 1956, observamos as intervenção no pavimento superior: o emprego de novos materiais nas paredes e a substituição do tabuado de madeira pela laje de Jussara. Fonte: desenhos elaborados a partir do KAMIMURA (1972) e levantamento "in loco". 
No corte BB demonstra as alterações feitas em 1956, nas paredes internas e externas do pavimento superior (em vermelho) onde o pau a pique original foi substituído por alvenarias de tijolos maciços comuns assentados com argamassa mista de terra, areia e cimento. A Fig. 15 apresenta a alvenaria de tijolos junto dos pilares de madeira com secção quadrada.

\subsection{Levantamento Fotográfico}

O levantamento a seguir ilustra vários detalhes das intervenções realizadas em 1956.

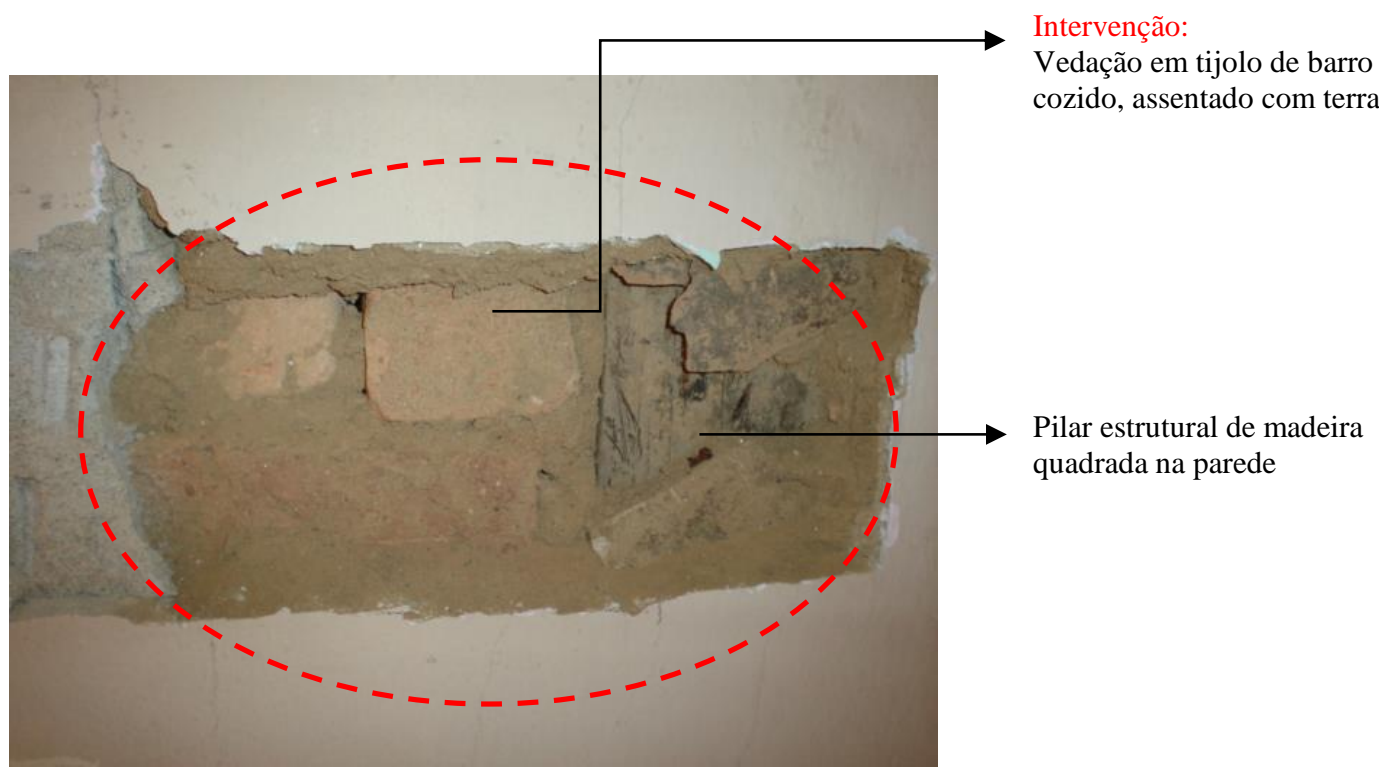

Figura 16: Detalhe do encontro de materiais distintos - tijolo e madeira - estrutura (2007)

Fonte: Jaccoud (2007)

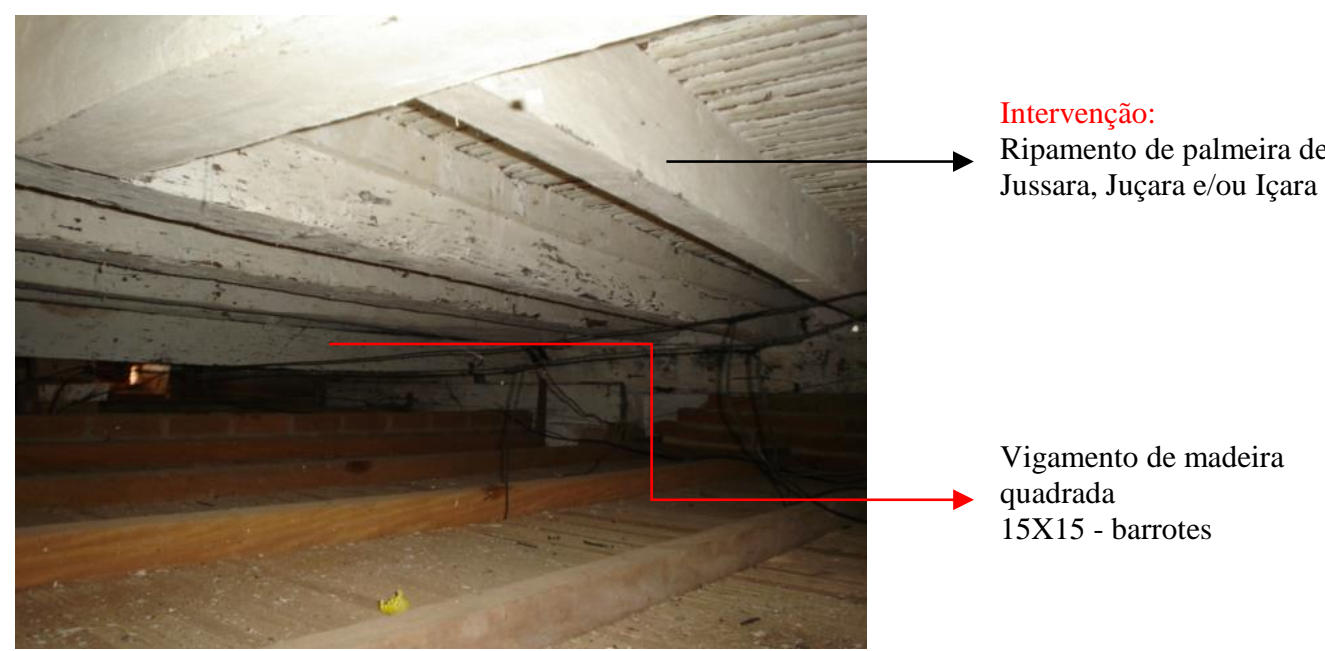

Figura 17: Vista entre o vão do forro do pavimento térreo e a estrutura de madeira com o ripamento de Jussara e/ou Içara pintada de branco - pavimento superior (2007)

Fonte: Jaccoud (2007) 
As Fig. 18 e 19 ilustram o detalhe do maciço da laje entre os pavimentos, executada em 1956, com massa de cimento, cal, areia e seixo rolado de rio, assentada sobre trama de Jussara. Sobre essa laje foi colocado um piso cerâmico nas áreas molhadas e as demais receberam tacos de madeira.

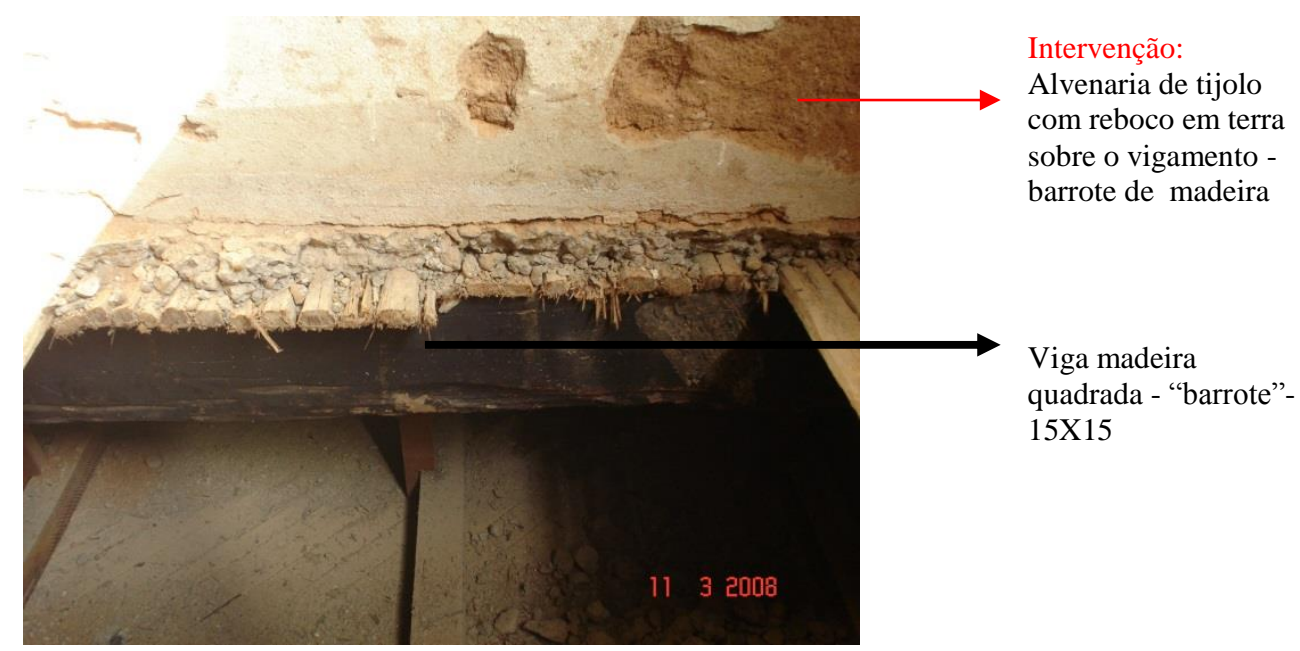

Figura 18: Parede de tijolo de barro cozido sobre o maciço - laje de Jussara, Juçara e/ou Içara (2008) Fonte: Jaccoud (2008)

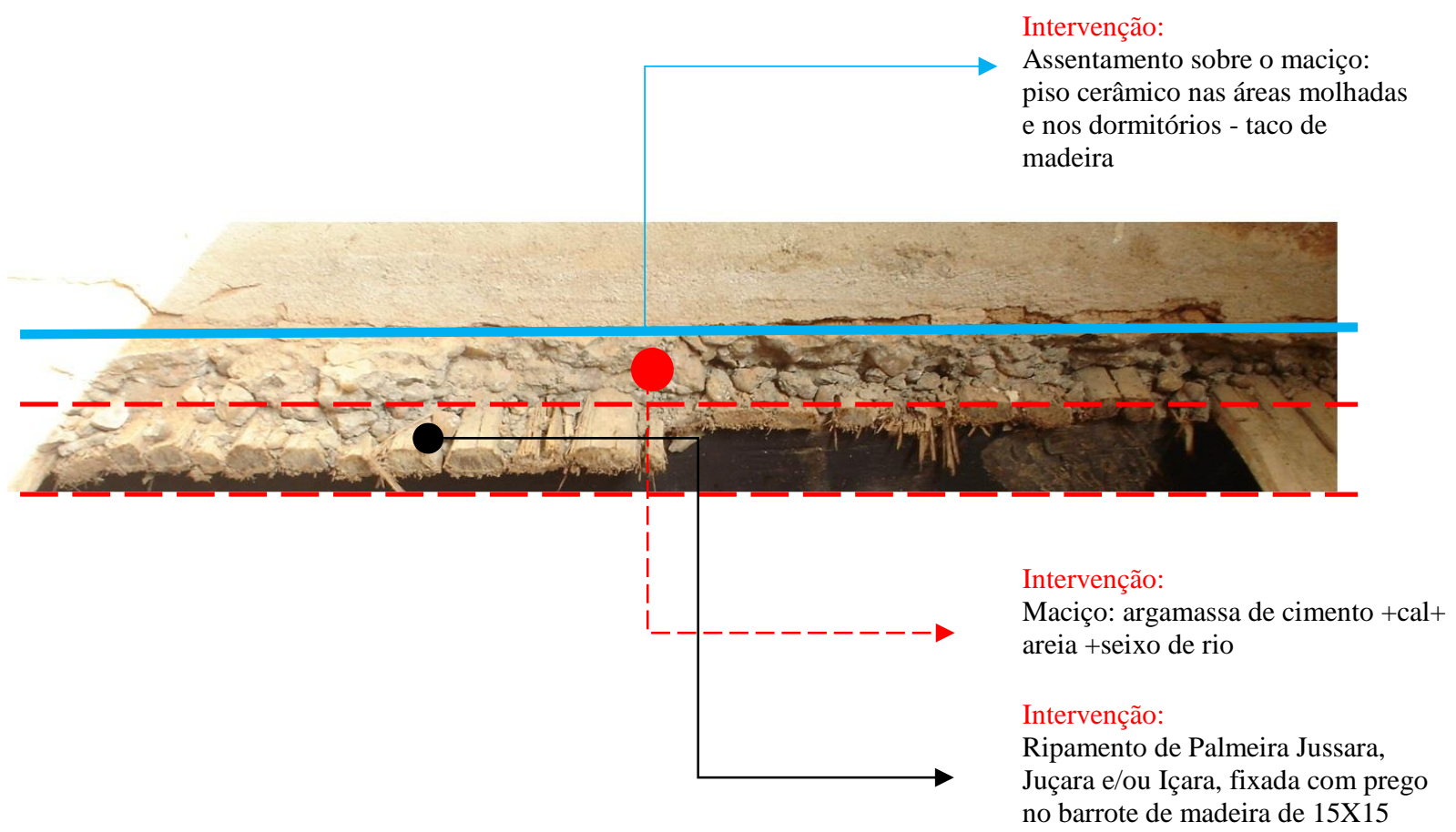

Figura 19: Detalhe do maciço da laje de ripamento de Jussara, Juçara e/ou Içara (2008)

Fonte: Jaccoud (2008) 


\section{CONSIDERAÇÕES FINAIS}

Este artigo detalha e documenta as intervenções realizadas em 1956 pelo Sr. João Guimarães, proprietário, de um edifício tombado na cidade de São Luís do Paraitinga - Estado de São Paulo. Esse edifício vem sendo um exemplar que se manteve íntegro após a inundação do Rio Paraitinga em janeiro de 2010.

A intervenção ocorreu anterior ao surgimento da Carta de Veneza de 1964, o seu tombamento em 1982 pelo Condephaat e pelo IPHAN em 2010, fato que justifica, em parte, os procedimentos construtivos elaborados na época.

Ao realizar uma intervenção em uma edificação pré-existente que tem uma importância histórica, a mesma deve ser interpretada, analisada minuciosamente para receber tal intervenção sem causar nenhuma sobreposição histórica que dificulte a compreensão da sua autenticidade. Tal prática em edifícios na arquitetura requer certos domínios e conhecimentos sobre a obra, ao realizar esta postura em um patrimônio edificado necessita de um conhecimento profundo. A intervenção em um patrimônio edificado necessita de uma interpretação do edifício, fato que sempre gerará polêmicas.

O objetivo da reforma ora analisada foi de preservar a integridade do edifício, solucionando as patologias presentes por meio da utilização das técnicas construtivas recorrentes na cidade de São Luís do Paraitinga em 1956, porém também foram modificadas algumas características originais, conforme os detalhes ora apresentados. Sobre essas questões Boito afirma que:

[...] diferença de estilo entre o novo e o velho; diferença entre os materiais de construção; supressão de linhas ou de ornatos; exposição das velhas partes removidas; incisão, em cada uma das partes renovadas, da data da restauração ou de um sinal convencionado; epígrafe descritiva e gravada sobre o monumento; descrição e fotografia dos diversos períodos das obras, expostas no edifício ou em local próximo a ele, ou ainda descrições em publicações; notoriedade. (BOITO, 2002, p.27)

Desta forma, toda e qualquer realização de intervenção em um edifício deve ser distinguível e possuir um registro minucioso desta prática, ideia basilar deste trabalho.

Concluímos que, os materiais e as técnicas utilizadas nesta intervenção eram distintos das técnicas originais da edificação e, que a partir desta, registra-se como documentação de testemunho, que serão importantes como base para os futuros restauros e intervenções a serem realizadas.

Enfim, os resultados desta pesquisa são fundamentais para as próximas decisões projetuais neste raro exemplar, e em outras edificações similares da cidade de São Luís do Paraitinga.

\section{REFERÊNCIAS}


BOITO, C. Os Restauradores. Trad. de Paulo M. Kühl e Beatriz M. Kühl. São Paulo: Ateliê Editorial, 2002.

CONDEPHAAT. Estudo de preservação e tombamento do núcleo histórico de São Luiz do Paraitinga: processo $n^{\circ}$ 22.066/82: resolução n55, São Paulo, 1982. 296 p.

CURY, I. Cartas Patrimoniais. $3^{\text {a }}$ ed. Revista e Aumentada. Rio de Janeiro: IPHAN, 2004. p.9293

GUIMARÃES, M.S. Informações dadas sobre a intervenção de 1956: Eduardo Adalberto Jaccoud Junior, São Paulo, jan./jun. 2018.

GUIMARÃES, R. Acervo fotográfico datado de 1921: propriedade particular de Maria Silvia Guimarães, São Luís do Paraitinga, 1921.

GuimarÃes, R.; GUIMARÃES, J. Capsula do Tempo: caderno de anotações. São Luís do Paraitinga, Museu da Igreja Matriz São Luís de Tolosa, 1927.

INFOPATRIMÔNIO. Preservação do patrimônio cultural brasileiro (beta). São Luiz do Paraitinga - Conjunto histórico e paisagístico. São Paulo, 2018. Disponível em: < http://www.infopatrimonio.org/?p=696\#!/map=38329\&loc=-23.21913372986319,-

45.29905557632446,15> Acesso em 16 jun. 2018.

IPHAN. Conjunto histórico e paisagístico de São Luiz do Paraitinga: processo ${ }^{\circ}$ 1590-T-10: livro histórico: $n^{\circ}$ inscr. 612, São Paulo, 2012.

JACCOUD JR, E. A. Acervo particular: Fotos anos 2007, 2008 e 2018, São Paulo.

KAMIMURA, Massayoshi. Levantamento Arquitetônico: plantas, cortes e fachadas, $\mathrm{n}^{\circ} 09$ e 10 , São Paulo, 1972.

LEMOS, C. C., Casa Paulista. São Paulo: EDUSP, 1999.

PISANI, Maria Augusta Justi. A Arquitetura de Terra. Revista Sinergia, São Paulo, v.5, p.9-15, jan./jun. 2004.

SAIA, Luís. Moradia Paulista. São Paulo: Perspectiva, 1972.

VASCONCELLOS, Sylvio de Carvalho. Arquitetura no Brasil: sistemas construtivos. 4.ed. Belo Horizonte: Escola de Arquitetura da Universidade Federal de Minas Gerais, 1961.

VERDE, Pedro Frazzaro; SCHICCHI, Maria Cristina da Silva. São Luiz do Paraitinga: da Reconstrução Pós-Enchente às Políticas de Prevenção e Conservação Urbana. Cadernos de Pós-Graduação em Arquitetura e Urbanismo da Faculdade de Arquitetura e Urbanismo da Universidade Presbiteriana Mackenzie, São Paulo: Ed.Mackenzie, 2013 v. 2013.1, p.01-25. Disponível em: <http://editorarevistas.mackenzie.br/index.php/cpgau/article/viewFile/Verde.2013.1/4468 Acesso em 26 ago. 2018. 